\title{
Perceived Stress and Nomophobia in Medical Faculty Students during COVID-19 Pandemic
}

\section{COVID-19 Pandemisinde Tıp Fakültesi Öğrencilerinde Algılanan Stres ve Nomofobi}

\author{
Merve Aktaş Terzioğlu 1(D), Tuğçe Toker Uğurlu 2(iD \\ 1. Pamukkale University, Faculty of Medicine, Department of Child and Adolescent Psychiatry, Denizli, Turkey \\ 2. Pamukkale University, Faculty of Medicine, Department of Psychiatry, Denizli, Turkey
}

\section{Abstract}

Objective: This study aimed at investigating the stress levels of medical students during the COVID-19 pandemic and their fear of being deprived of their mobile phones (nomophobia).

Method: An online questionnaire consisting of the Perceived Stress Scale (PSS), Nomophobia Scale (NMP-Q) and sociodemographic data was completed with the participation of 341 students.

Results: The use of smartphones increased during the COVID-19 pandemic andthis increase was statistically similar in both sexes. According to NMP-Q results, $67 \%$ of females were mildly, $32.1 \%$ were moderate, and $0.9 \%$ were severe nomophobic. Of the males $55 \%$ were mildly, while $39.3 \%$ were moderate, and $5.7 \%$ were found to be severe nomophobic. It was determined that the mean PSS scores of males were significantly higher than females. Mean scores of PSS and NMP-Q for students aged 20 and under were found to be similar to those of students over 20. There was a positive correlation between PSS scores and all dimensions of NMP-Q.

Conclusion: Medical faculty students were found to be mild/moderate level nomophobic. During the COVID-19 pandemic, male medical students were more affected than female students, they felt greater stress, and had a higher tendency toward nomophobia.

Keywords: Mobile phone addiction, nomophobia, stress, COVID-19

Öz

Amaç: Tıp fakültesi öğrencilerinin COVID-19 pandemisi sırasında algıladıkları stres ve cep telefonlarından mahrum kalma korkusunun (nomofobi) araştıııması amaçlanmıştır.

Yöntem: Algılanan Stres Ölçeği (ASÖ), Nomofobi Ölçeği (NÖ) ve sosyodemografik verilerden oluşan çevrimiçi anket 341 öğrencinin katılımılla tamamlandı.

Bulgular: COVID-19 pandemisi sırasında akıllı telefon kullanımının her iki cinsiyette istatistiksel olarak benzer şekilde arttığı bildirildi. NÖ'ye göre, kadınların \%67'si hafif, \%32,1'i orta, \%0,9'u aşııı derecede nomofobikken; erkeklerin \%55'i hafif, \%39,3'ü orta ve \%5,7'si aşııı derecede nomofobikti. Erkeklerin ortalama ASÖ puanlarının kadınlardan anlamlı derecede yüksek olduğu bulundu. 20 yaș ve altındaki öğrencilerin ASÖ ve NÖ puan ortalamalarının 20 yaşın üzerindeki öğrencilerin puanlarına benzer olduğu görüldü. ASÖ puanları ile NÖ’nün tüm boyutları arasında pozitif bir korelasyon vardır.

Sonuç: Tıp fakültesi öğrencileri hafif/orta düzeyde nomofobik bulundu. COVID-19 pandemisi sırasında erkek tıp öğrencilerinin kız öğrencilere göre daha fazla etkilendikleri, kendilerini stres altında hissettikleri ve nomofobi eğilimlerinin daha yüksek olduğu saptandı.

Anahtar kelimeler: Akıllı telefon bağımlılığı, nomofobi, stres, COVID-19 


\section{Introduction}

Starting in December 2019, the COVID-19 pandemic (2019-nCoV or SARS-CoV-2) has caused a massive healthcare crisis, severely restricted social interaction and mobility of millions of people, and caused the closure of schools and universities (1-4). With the closure of schools and dormitories, many students have returned to live with their families and have been detached from the university and social environment. Studies show that public health emergencies have caused psychiatric symptoms in university students, such as anxiety and fear $(5,6)$. Since university students have little to no economic freedom and they are in the transition from adolescence to adulthood, it is often considered that they are more fragile with respect to mental health $(7,8)$.

In studies examining the effects of COVID-19 on mental health, the negative effects of the pandemic, in particular with respect to stress, anxiety and depression, were confirmed (5,9-12). According to recent reports, it has been found that curfews and social isolation had a trigger effect on mental health deterioration $(13,14)$.

It is well-known that stress has a negative effect on mental health. While stress has a negative effect on functionality, prolonged exposure to stress causes physical and mental health problems, affects daily behavior, and reduces the quality of life (15-17). Stress can also affect learning and memory (18). Computers and smartphones have significantly changed the learning and teaching environment. Today, while telephone use has increased with advances in technology, it is believed that with the COVID-19 pandemic, time spent with mobile phones increased even more due to social isolation, and this was substituted for face-to-face interactions. Nomophobia is a term devised from "no mobile phobia." It has been defined as an unrealistic fear, experienced by an individual who cannot access his/her mobile phone, leading to a failure to communicate (19). The results of nomophobia can cause concentration problems, insomnia, decreased performance, and stress (20).

In addition to the stress-related mental effects of the COVID-19 pandemic on medical students, the interruption of face-to-face education within the framework of protective measures for this age group and mandatory social isolation and quarantine applied to youth under 20 years of age, stress perception has increased. As an indirect effect, the use of smartphones has increased the tendency toward nomophobia during the pandemic. During this unique situation, the smartphone has become a major connector for communicating via internet, phone, online courses, online games, and shopping as a means to cope with stress and participate in leisure activities.

The objective of this study was to investigate the stress levels of medical faculty students during COVID-19 pandemic and their tendency towards fear of deprivation of their mobile phone (nomophobia). This study will make an important contribution to the literature as it evaluates the relationship between stress and nomophobia in medical faculty students during the COVID-19 pandemic. In addition, nomophobia is important as it is a very current topic like the psychological effects of COVID-19 pandemic.

\section{Method}

\section{Participants}

Ethical approvals have been obtained from the Republic of Turkey, Ministry of Health, R\&D Scientific Research Studies (dated June 13, 2020) and Pamukkale University Faculty of Medicine, Ethics Committee (dated June 23, 2020 and numbered 12). All participants provided online informed consent before attending into the study.

The study is a cross-sectional epidemiological study. The data of the study were collected between June and July 2020, and the population consisted of six classes students $(n=1380)$ enrolled in the 2019-2020 academic year of a medical school located in the Aegean region. The sample size was calculated with the 
formula used in cases where the population size is known, and it was found to be a minimum of 300 participants. A total of 341 students fully completed the questionnaire and their data were evaluated. All students who agreed to participate and completed the questionnaire were included in the study and no exclusion criteria was set.

\section{Procedure}

Study data has been collected in the form of an online questionnaire, following the suspension of face-toface education by universities resulting from COVID-19 precautions. Following consents, student representatives from all six classes were reached by telephone/e-mail and the questionnaires were distributed. While preparing the survey, all of the questions were stated as mandatory, and it was not possible to move on to the next question without answering the questions in order. If the participant did not answer the question, did not complete the questionnaire and was excluded from the study. The online survey system prevents refilling the scale from the same internet port (IP) address. In this way, each participant filled out the questionnaire only once.

Data was collected in the form of a 52-question online questionnaire, using the Perceived Stress Scale (PSS), the Nomophobia Questionnaire (NMP-Q) and sociodemographic data forms, which were created by the researchers.

\section{Measures}

\section{Sociodemographic Data Form}

In the sociodemographic data form created by the researchers, information was collected about the gender, age of the participants, which class are they, education and income levels of their parents, and family structure. In addition, they were asked whether the COVID-19 pandemic affected them mentally. Also, data on phone usage features such as whether there was an increase in smartphone use during the pandemic period, average phone usage time per day, frequency of phone checking, and the purpose of use of the phone were questioned.

\section{Perceived Stress Scale (PSS)}

The PSS, developed by Cohen et al. (1983), consists of 14 questions, which have been validated in Turkish. It is a self-reporting scale, where the participants rank each item from "never" (0) to "very frequently" (4). The PSS measures the level of stress, perceived for certain situations in the life of an individual. The Turkish PSS internal consistency coefficient was calculated as 0.84 and test-retest reliability coefficient was calculated as $0.87(21,22)$.

\section{The Nomophobia Questionnaire (NMP-Q)}

The NMP-Q, created by Yıldırım and Correira, whose validity and reliability has been proven in Turkish, is a seven-point Likert-type self-reporting scale (23). The minimum score is 20, obtained by scoring 1 point for each question; the maximum score is 140, obtained by scoring 7 points for each question. Scores between 21 and 59 are described as mildly nomophobic; 60-99, is rated moderately nomophobic; and over 100 is considered severely nomophobic. Cronbach's alpha value of the scale, adapted to Turkish, is 0.92. The NMP-Q has been divided into four sub-categories, namely, losing online connection, inability to communicate, to give up comfort and inability to access information. Cronbach alpha values of the subcategories of scales, have been reported as $0.90,0.74,0.94$ and 0.91 , respectively (24).

\section{Statsitical Analysis}

SPSS (Statistical Package for Social Sciences) Version 22.0 was used to evaluate data. As descriptive statistics, frequency (n), percentage (\%), mean and standard deviation (SD) have been used. In comparison to qualitative data, Pearson's Chi-square (x2) test was used. The consistency of data with normal distribution was assessed with the Shapiro-Wilk normality test and skewness and kurtosis coefficients. In comparison to qualitative data, on the provision of compliance with normal distribution, İndependent T- 
tests were used. Relationships between the quantitative data were assessed using Pearson's Correlation Test. In all analyses, significance value at 95\% confidence interval is accepted as $p<0.05$.

\section{Results}

Of all participating students, males comprised $67.2 \%(n=229)$, while $32.8 \%(n=112)$ consisted of female students. As for distribution by classes, students of 1st, 2nd, 3rd, 4th, 5th, and 6th classes were respectively, 22.9\% $(n=78), 10.6 \%(n=36), 23.5 \%(n=80), 9.7 \%(n=33)$ and $16.7 \%(n=57)$. The average

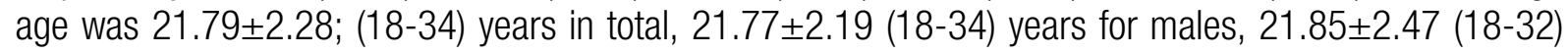
years for females. Participants were found to be similar according to gender with respect to age $(p=0.763)$, mother's age $(p=0.637)$, father's age $(p=0.963)$, family structure $(p=0.998)$, domicile of family $(p=0.681)$, total household income $(p=0.968)$, and father's educational status $(p=0.883)$. As for mother's educational status, it was determined that uneducated status was more common among the mothers of females (7.1\%) $(p=0.030)$ (Table 1).

Table 1. Comparison of the sociodemographic characteristics of medical students by gender

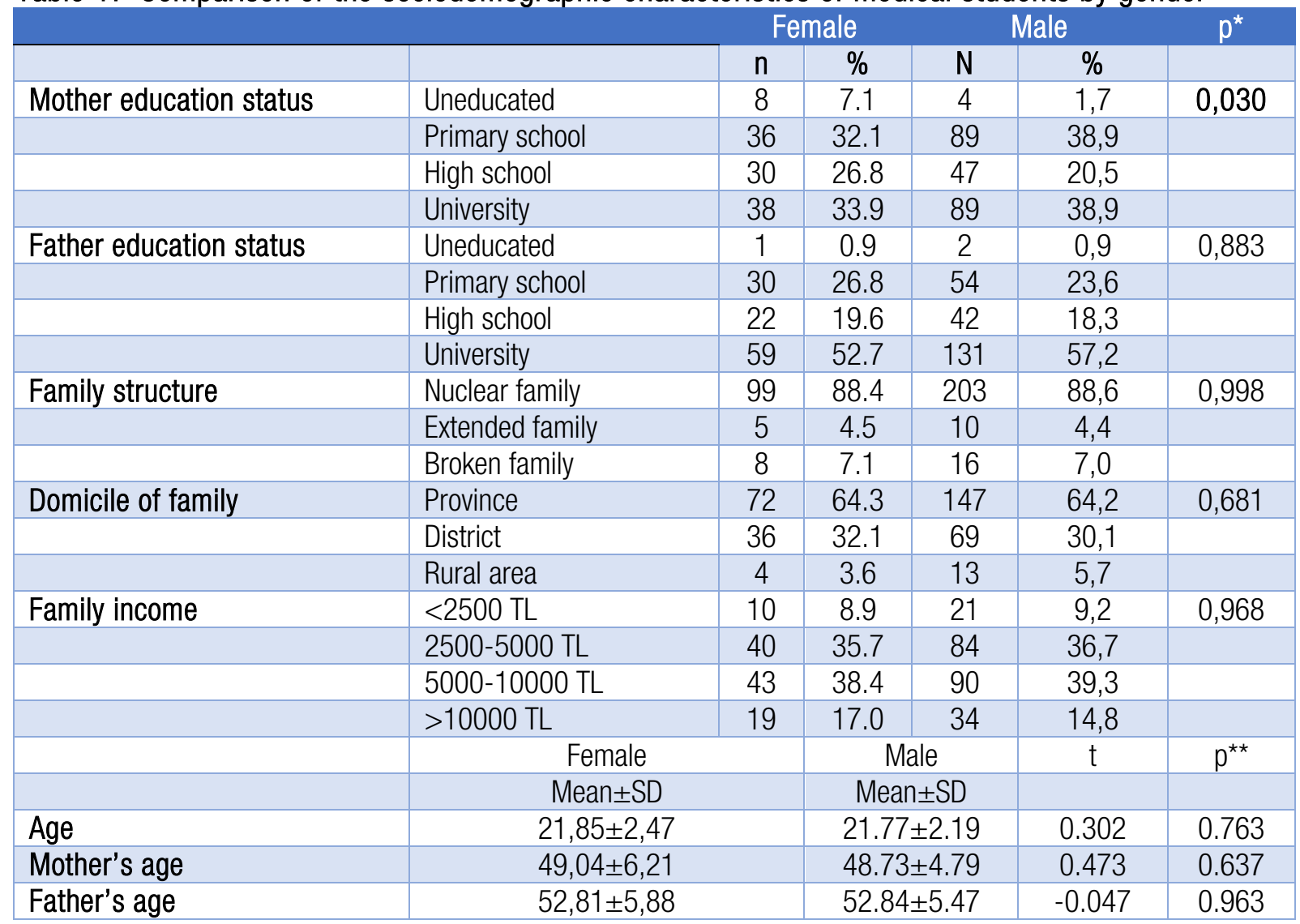

*Pearson $\chi 2$ Test; **Independent T test; SD: standard deviation

More male students (90.8\%) than female students (83\%) indicated that "COVID-19 pandemic mentally affected them" $(p=0.036)$. Both genders reported in a statistically similar manner that their smartphone use increased during COVID-19 ( $p=0.936)$. For males (31.4\%) and females (37.5\%), daily average phone use time was similar at $4-6$ hours $(p=0.213)$. Checking one's phone immediately after waking up was also similar at a high rate for both genders $(p=0.838)$ (Table 2$)$.

The NMP-Q average total score was $58.56 \pm 20.14$ (21-137) for the entire group. In males, the average NMP-Q total score was calculated as $61.15 \pm 21.13$ (21-137), and in females as 53.26 \pm 16.85 (28-104), and the difference was statistically significant $(p<0.001)$. According to the NMP-Q, totally $58.9 \%$ of students were found to be mildly nomophobic, $37 \%$ moderate nomophobic and $4.1 \%$ severe nomophobic. When evaluated the NMP-Q according to gender $67 \%$ of females were found to be mildly nomophobic, 
$32.1 \%$ moderate, and $0.9 \%$ severe nomophobic. In males it was determined that $55 \%$ were mildly, $39.3 \%$ moderate, and $5.7 \%$ were determined to be severe nomophobic. In an assessment made according to NMP-Q subgroups, while losing online connection $(p=0.345)$ and inability to access information $(p=0.770)$ were found to be similar between genders, inability to communicate $(p<0.001)$ and to give up comfort $(p<0.001)$ were found to be higher among males compared to females. The NMP-Q total and subscale assessments are given in Table 3.

Table 2. Comparison of the effects of COVID-19 pandemic on mental state and telephone use of medical students by gender

\begin{tabular}{|c|c|c|c|c|c|c|}
\hline \multicolumn{2}{|l|}{ 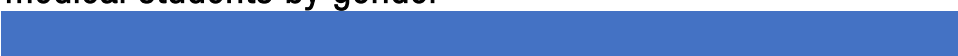 } & \multicolumn{2}{|c|}{ Female } & \multicolumn{2}{|c|}{ Male } & \multirow[t]{2}{*}{$p^{*}$} \\
\hline & & $\mathrm{n}$ & $\%$ & $\mathrm{n}$ & $\%$ & \\
\hline \multirow{2}{*}{$\begin{array}{l}\text { Thinking mentally affected during the COVID-19 } \\
\text { pandemic }\end{array}$} & Yes & 93 & 83.0 & 208 & 90.8 & 0.036 \\
\hline & No & 19 & 17.0 & 21 & 9.2 & \\
\hline \multirow{2}{*}{$\begin{array}{l}\text { Thinking the smartphone use has increased during } \\
\text { the COVID-19 pandemic }\end{array}$} & Yes & 95 & 84.8 & 195 & 85.2 & 0.936 \\
\hline & No & 17 & 15.2 & 34 & 14.8 & \\
\hline \multirow[t]{4}{*}{ Average phone usage time per day } & $0-2$ hours & 11 & 9.8 & 24 & 10.5 & 0.213 \\
\hline & 2-4 hours & 39 & 34.8 & 69 & 30.1 & \\
\hline & 4-6 hours & 42 & 37.5 & 72 & 31.4 & \\
\hline & $>6$ hours & 20 & 17.9 & 64 & 27.9 & \\
\hline \multirow{2}{*}{$\begin{array}{l}\text { Checking the phone when you wake up in the } \\
\text { morning }\end{array}$} & Yes & 104 & 92.9 & 214 & 93.4 & 0.838 \\
\hline & No & 8 & 7.1 & 15 & 6.6 & \\
\hline
\end{tabular}

*Pearson $\chi 2$ Test

The PSS score average was $31.64 \pm 4,13$ (14-42) for the entire group. PSS average scores were $32.59 \pm 3.72$ (24-42) in males, and 29.71 \pm 4.27 (14-38) in females. The difference was statistically significant $(p<0.001)$. The PSS score assessment is shown in Table 3.

Table 3. Comparison of Perceived Stress and Nomophobia Scale scores of medical students during COVID-19 pandemic by gender and being under - 20 years old

\begin{tabular}{|l|c|c|c|c|c|}
\hline & \multicolumn{5}{|c|}{ Female } \\
\hline
\end{tabular}

*Pearson $\chi 2$ test; ${ }^{\star \star}$ Independent T test; SD: standard deviation; NMP-Q: The Nomophobia Questionnaire 
To assess indirect effects of quarantine and social isolation, scores of students below and over 20 years of age were separately assessed. PSS $(p=0.089)$ and NMP-Q $(p=0.467)$ average scores of students below 20 years of age, were found statistically similar to those of students above 20 years of age and these are shown in Table 3.

Table 4. The relationship between the Perceived Stress and Nomophobia Scale scores of medical students during the COVID-19 pandemic

\begin{tabular}{|l|c|c|} 
& \multicolumn{3}{c|}{ Perceived Stress Scale } \\
\hline NMP-Q & $r$ & $\mathrm{p}^{*}$ \\
\hline NMP-Q - Losing online connection & 0.243 & $<0.001$ \\
\hline NMP-Q -Inability to communicate & 0.130 & 0.017 \\
\hline NMP-Q -To give up comfort & 0.295 & $<0.001$ \\
\hline NMP-Q -Inability to access information & 0.179 & 0.001 \\
\hline
\end{tabular}

${ }^{*}$ Pearson Correlation Test; NMP-Q: The Nomophobia Questionnaire

The relationship between PSS and NMP-Q totals and all sub-scores was assessed. Accordingly, between the PSS and NMP-Q scores, a statistically significant positive, weak, or very weak correlation was determined $(p>0.05)$. The tendency toward nomophobia increased with an increase in stress points (Table 4).

\section{Discussion}

This study aimed to investigate frequency of nomophobia and stress perceptions of medical students during the COVID-19 pandemic. As a result of the study, stress perception and nomophobia tendencies have been found to be high among medical students, particularly in males. In addition, the tendency toward nomophobia shows an increase with increasing stress points.

Male students defined that COVID-19 affected them more mentally compared to females. In a limited number of studies, it has been found that perceived stress level was higher among females in COVID-19 $(14,25)$. In these studies, it was thought that females had many responsibilities both at home and at work, and therefore they were more affected by stress than males and the stress experienced by females increases their anxiety levels and this situation continues during the epidemic period $(14,25)$. Another study determined that female students used planned problem solutions and acceptance of responsibility more than male students as methods to cope with stress $(25,26)$. In the face of stress, students use some functional or dysfunctional strategies. This situation also reveals how they cope with stress. Coping is directed at mitigating the perceived threat and consequent destruction (26). Differences in coping strategies between genders is also reflected in stress perception $(27,28)$.

Anxiety of university students related to COVID-19 may also be associated with possible negative effects of the pandemic on their education and professional lives, along with disease contraction, negative effects of social media, decrease of communication and isolation (29-33). In this study, it was thought that coping skills of males could be lower, and, therefore, their stress perceptions increased in times of the pandemic.

The use of smartphones by students increased during the pandemic. This may be explained by many reasons, such as social isolation, transformation of face-to-face communication to online communication, methods of coping with increased stress and online classes. Similar to stress perception, in this study, nomophobia tendencies were found to be higher in males. In a study conducted with high school students, the rate of nomophobia was found to be higher in males, similar to this study (34). There are studies that indicated that the reason for differences between genders, could be mental and economic $(34,35)$. Positive correlations between stress and nomophobic tendencies, has been interpreted in support of this conclusion.

According to the results in this study, on average, most students use their phones for four to six hours per day. Previous studies indicate that increased phone use was directly proportional with the level of 
nomophobia (36). Checking one's phone immediately after waking up was also found to be similar at a high rate in both genders. According to the literature, most people who had the habit of checking their phones upon awaking, had moderate nomophobia; however, those who did not, were determined to be nomophobic at low levels $(37,38)$. There are studies that support the view that nomophobia can be seen as an addiction (39). Due to the repetitive behavior of checking one's phone upon awakening and longterm phone use, this is consistent with the definition of addiction (40).

Nomophobia has been observed in all youth and this may be interpreted as pointing to a behavioral addiction. In this study, a significant relationship between the increase of stress levels and nomophobia was found, and it is plausible to interpret this relationship with respect to addiction. The tendency toward addiction increases with an increase in stress and anxiety. One study of medical students discovered that those with higher internet addiction scores were more anxious than students with lower scores (41). In another study investigating the relationship between depression, a moderate positive significant correlation between social media addiction scores and anxiety and stress symptoms was reported (42). A positive correlation has been determined in many studies in literature (43-45).

In Turkey, within the precautions of COVID-19 pandemic, additional measures have been adopted for individuals below 20 and over 65 years of age in addition to nationwide curfews on weekends, national holidays, and feasts. In literature, there are studies, demonstrating a positive correlation between addiction and isolation $(41,46)$. In addition, strict precautions, such as social isolation rules, increase the level of anxiety and stress in children and adolescents (47). However, no significant difference in stress and nomophobia levels have been detected in students below and over 20 years of age in the current research. This conclusion may imply that youth over 20 years of age had a similar experience of effects of restrictions due to curfews on weekends, holidays, closure of spaces for socializing [schools, cafes, sports halls, etc.], and proximity to others their age.

The most important limitation of the study was the inability to reach all students due to online data collection. Since face-to-face education had not yet begun in Turkish universities, online collection of data was mandatory as well as safe during the continuing COVID-19 pandemic. Despite these limitations, it is believed that the number of participating students were sufficient.

Consequently, medical faculty students were found to be mild/moderate nomophobic. This can be interpreted as the decrease in face-to-face communication and social environment during the COVID-19 pandemic process, leaving its place to digital communication and social networks. Also it was seen that male medical students were more nomophobic and perceived themselves as more stressful compared to female students in COVID-19 pandemic. At the same time, for all students, nomophobia tendency increased with an increase in perceived stress. In addition, revealing the connection between stress and nomophobia in the sample of medical faculty students contains important clues in terms of combating nomophobia. In medical education, which is a very stressful educational process, measures can be taken to improve the skills of coping with stress and the social environment in order to reduce both the perceived stress and the frequency of nomophobia in students. It is thought that future studies could best support the findings of this study with a larger sample size and control groups.

\section{References}

1. Jiao WY, Wang LN, Liu J, et al. Behavioral and emotional disorders in children during the COVID-19 epidemic. J Pediatr 2020; 221: 264-266.e1.

2. Lu R, Zhao X, Li J, et al. Genomic characterisation and epidemiology of 2019 novel coronavirus: implications for virus origins and receptor binding. Lancet 2020; 395(10224): 565-574.

3. Fauci AS, Lane HC, Redfield RR. Covid-19 - Navigating the uncharted. N Engl J Med 2020; 382): 1268-1269.

4. Davico C, Ghiggia A, Marcotulli D, et al. Psychological impact of the COVID-19 pandemic on adults and their children in Italy. Front Psychiatry 2021; 12: 572997.

5. Cao W, Fang Z, Hou G, et al. The psychological impact of the COVID-19 epidemic on college students in China. Psychiatry Res 2020; 287: 112934. 
6. Mei S, Yu J, He BW, et al. Psychological investigation of university students in a university in Jilin Province. Med Soc 2011; 24(5): 84-86.

7. Auerbach RP, Mortier P, Bruffaerts R, et al. WHO world mental health surveys international college student project: prevalence and distribution of mental disorders. J Abnorm Psychol 2018; 127(7): 623-638.

8. Rubley JN. The student-centered university: Pressures and challenges faced by college presidents and student affairs leaders. Chron High Educ 2017; 3-26.

9. Hao F, Tan W, Jiang L, et al. Do psychiatric patients experience more psychiatric symptoms during COVID-19 pandemic and lockdown? A case-control study with service and research implications for immunopsychiatry. Brain Behav Immun 2020; 87: 100-106.

10. Huang Y, Zhao N. Generalized anxiety disorder, depressive symptoms and sleep quality during COVID-19 outbreak in China: a web-based cross-sectional survey. Psychiatry Res 2020; 288: 112954.

11. Lai J, Ma S, Wang Y, et al. Factors associated with mental health outcomes among health care workers exposed to coronavirus disease 2019. JAMA Netw Open 2020; 3(3): e203976.

12. Rajkumar RP. COVID-19 and mental health: A review of the existing literature. Asian J Psychiatr 2020; 52: 102066.

13. Wang $C$, Pan $\mathrm{R}$, Wan $\mathrm{X}$, et al. A longitudinal study on the mental health of general population during the COVID19 epidemic in China. Brain Behav Immun 2020; 87: 40-48.

14. Wang $C$, Pan $R$, Wan $X$, et al. Immediate psychological responses and associated factors during the initial stage of the 2019 coronavirus disease (COVID-19) epidemic among the general population in China. Int J Environ Res Public Health 2020; 17(5): 1729.

15. Çevik A, Şentürk V. Historical development of psychosomatic medicine and review of psychosomatic disorders. Türkiye Klinikleri Psikiyatri-Özel Konular 2008; 1(2): 1-11.

16. Schneiderman N, Ironson G, Siegel SD. Stress and health:psychological, behavioral, and biological determinants. Annu Rev Clin Psychol 2005; 1: 607-628.

17. Taylor AH, Dorn L. Stress, fatigue, health, and risk of road traffic accidents among professional drivers: the contribution of physical inactivity. Annu Rev Public Health 2006; 27: 371-391.

18. Shors TJ. Stressful experience and learning across the lifespan. Annu Rev Psychol 2006; 57: 55-85.

19. King AL, Valença AM, Silva AC, et al. "Nomophobia": Impact of cell phone use interfering with symptoms and emotions of individuals with panic disorder compared with a control group. Clin Pract Epidemiol Ment Health 2014; 10: 28-35.

20. Augner C, Hacker GW. Associations between problematic mobile phone use and psychological parameters in young adults. Int J Public Health 2012; 57(2): 437-441.

21. Cohen S, Kamarck T, Mermelstein R. A global measure of perceived stress. J Health Soc Behav 1983; 24(4): 385-396.

22. Eskin M, Harlak H, Demirkıran F, et al. The adaptation of the perceived stress scale into Turkish: A reliability and validity analysis. Yeni Symposium 2013; 51(3): 132-140.

23. Yildirm C, Correia AP. Exploring the dimensions of nomophobia: Development and validation of a self-reported questionnaire. Comput Human Behav 2015; 49: 130-137.

24. Yildırm C, Sumuer E, Adnan M, et al. A growing fear: Prevalence of nomophobia among Turkish college students. Inf Dev 2016; 32(5): 1322-1331.

25. Göksu Ö, Kumcağız H. Perceived stress level and anxiety levels in individuals in Covid-19 outbreak. Turkish Studies 2020; 15(4): 463-479.

26. Savcı M, Aysan F. The relationship between the perceived stress level and the stress coping strategies in university students. International Journal of Turkish Education Sciences 2014; 2(3): 44-56.

27. Misra R, McKean M, West S, et al. Academic stress of college students: Comparison of student and faculty perceptions. College Student Journal 2000; 34(2): 236-245.

28. Aysan F, Özben Ş. Coping Strategies Used by a group of elderly living in nursing homes. Ege Eğitim Dergisi 2004; 2(5): 1-12.

29. Cornine A. Reducing nursing student anxiety in the clinical setting: An integrative review. Nurs Educ Perspect 2020; 41(4): 229-234.

30. Wang C, Horby PW, Hayden FG, et al. A novel coronavirus outbreak of global health concern. Lancet 2020; 395(10223): 470-473.

31. Xiao C. A Novel approach of consultation on 2019 novel Coronavirus (COVID-19)-related psychological and mental problems: Structured letter therapy. Psychiatry Investig 2020; 17(2): 175-176.

32. Bao Y, Sun Y, Meng S, et al. 2019-nCoV epidemic: Address mental health care to empower society. Lancet 2020; 395(10224): e37-e38. 
33. Ayittey FK, Ayittey MK, Chiwero NB, et al. Economic impacts of Wuhan 2019-nCoV on China and the world. J Med Virol 2020; 92(5): 473-475.

34. Durak HY. Investigation of nomophobia and smartphone addiction predictors among adolescents in Turkey: Demographic variables and academic performance. Soc Sci J 2019; 56(4): 492-517.

35. Burucuoğlu M. A research on nomophobia levels of vocational college students. Karabuk University Journal of Institute of Social Science 2017; 7(2): 482-489.

36. Erdem H, Türen U, Kalkın G. No Mobile Phone Phobia (Nomophobia) prevalence: samples of undergraduate students and public employees from Turkey. Bilişim Teknolojileri Dergisi 2017; 10(1): 1-12.

37. Akıllı GK, Gezgin DM. Üniversite öğrencilerinin nomofobi düzeyleri ile farklı davranış örüntülerinin arasındaki ilişkilerin incelenmesi. Mehmet Akif Ersoy Üniversitesi Eğitim Fakültesi Dergisi 2016; 40: 51-69.

38. Eren B, Kiliç ZN, Günal SE, et al. Evaluation of nomophobia and related factors in high school students. Anadolu Psikiyatri Derg 2020; 21(2): 133-140.

39. De-Sola Gutiérrez J, Rodríguez de Fonseca F, Rubio G. Cell-phone addiction: A review. Front Psychiatry 2016; 7: 175.

40. Şar AH, Işıklar A. Adaptation of problem mobile phone use scale to Turkish. International Journal of Human Sciences 2012; 9(2): 264-275.

41. Yücens B, Üzer $A$. The relationship between internet addiction, social anxiety, impulsivity, self-esteem, and depression in a sample of Turkish undergraduate medical students. Psychiatry Res 2018; 267: 313-318.

42. Bilge Y, Baydili KN, Göktaş SŞ. Sosyal Medya Bağımlılı̆ını Yordamada Anksiyete, Stres ve Günlük Sosyal Medya Kullanımı: Meslek Yüksekokulu Örneği. Bağımlılık Dergisi 2020; 21(3): 223-235.

43. Lin CY, Broström A, Nilsen P, et al. Psychometric validation of the Persian Bergen Social Media Addiction Scale using classic test theory and Rasch models. J Behav Addict 2017; 6(4): 620-629.

44. Demirci I. The adaptation of the Bergen Social Media Addiction Scale to Turkish and its evaluation of relationship with depression and anxiety symptoms. Anadolu Psikiyatri Derg 2019; 20(1): 15-22.

45. Elhai JD, Hall BJ, Erwin MC. Emotion regulation's relationships with depression, anxiety and stress due to imagined smartphone and social media loss. Psychiatry Res 2018; 261: 28-34.

46. Müezzin $E$. An investigation of high school students' internet addiction with respect to withdrawal, controlling difficulty, disorder in functionality and social isolation. Sakarya University Journal of Education 2017; 7(3): 541551.

47. Aykut S, Aykut SS. The importance of social work on the basis of post-traumatic stress disorder and the Covid19 pandemic. Toplumsal Politika Dergisi 2020; 1(1): 56-66. 